\title{
NurseLine Journal
}

Vol. 6 No. 2 November 2021 p-ISSN 2540-7937 e-ISSN 2541-464X

\section{PARENTAL READINESS IN CARING FOR LOW BIRTH WEIGHT: PEDIATRIC NURSING INTERVENTION}

\author{
Novi Indrayati ${ }^{1 *}$, Dona Yanuar Agus Santoso ${ }^{2}$ \\ ${ }^{1}$ Nursing Science Study Program (Pediatric Nursing, Sekolah Tinggi Ilmu Kesehatan Kendal, Indonesian ) \\ ${ }^{2}$ Nursing Science Study Program (Community Health Nursing, Sekolah Tinggi Ilmu Kesehatan Kendal, \\ Indonesa) \\ *e-mail:noviindrayati68@gmail.com
}

\begin{abstract}
Low birth weight (LBW) weighing less than 2500 gramsare babies at high risk because in general, they are smaller than normal birth weight babies and immature organ function. LBW requires special care to anticipate life-threatening emergency conditions. The care process for meeting the special needs of LBW requires the involvement of parents during the hospital and after discharge from the hospital. Nurses as educators have an important role in preparing parents to care for LBW after returning from the hospital. This study aims to determine the effect of child nursing interventions through the education of LBW infant care with parents' readiness to care for LBW. This research is a quantitative study, using a quasi-experimental design with a pre-post-test with control. The population of this study was parents who had LBW babies in Kendal District Hospital with the sampling technique using accidental sampling, the total sample was 40 parents with LBW babies. The sample was classified into two groups, namely, 20 respondents as the intervention group and 20 respondents as the control group. The results of this study indicate that there was a significant differences in parent readiness scoresin caring for LBW between those who were given and not given education with a $P$ value of 0.000 , used an independent sample t-testand there was an effect of education on the readiness of parents in caring for LBW used the Chi-square test with a p value of 0.002 . Providing education to parents with LBW is one of the implementations of pediatric nursing to prepare parents to care for LBW.
\end{abstract}

Keywords:

education

LBW

Parent Readiness

Pediatric nursing intervention

\section{BACKGROUND}

Neonates are individuals who are experiencing a growth process and have just undergone the birth process and require adaptation from within the uterus to extrauterine life (Sembiring, 2019). Neonates can have several health problems such as sepsis. Research conducted at Sanglah General Hospital Denpasar, Bali on the incidence and factors associated with sepsis in neonates, showed that from 125 cases of neonatal sepsis studied, $56 \%$ of low birth weight (Putra, 2016).

LBW including high-risk babies, this is because babies are born with low birth weight, generally accompanied by an immature body. Neonatal basic needs such as maintenance of breathing, ex- tra-uterine circulation patterns, nutrition, control and maintenance of body temperature, elimi-nation, prevention of infection, the for-mation of parent-infant relationships, and developmental needs must be assessed as soon as possible (Reeder \& Griffin, 2011).

LBW is one of the risk factors for infant mortality, to prevent infant mortality, proper handling of LBW is needed. The cause of LBW is that pregnant women experience anemia, lack of nutritional intake while in the womb, or are born at fewer months. LBW is very prone to hypothermia and the formation of immature body organs, this can be the main cause of infant death so LBW needs serious handling. The percentage of LBW in Central Java in 2017 was 4.4 percent, while in 2018 it was 4.3 percent(Central Java Province Health Office, 2017). LBW must get spe- 
cial care that is different from normal babies in general to maintain their condition. LBW treatment can be done by maintaining body temperature, preventing infection, monitoring nutrition/breast milk, and monitoring body weight (Rukiyah, 2012).

LBW treatment in the NICU room is an unexpected eventparent and can cause anxiety. Based on the results of the study, $50 \%$ of mothers who had LBW babies who were treated in the perinatology room experienced moderate anxiety levels, $31.2 \%$ experienced severe anxiety and $18.8 \%$ experienced mild anxiety(Wahyu Hendiyanto, 2014). Other studies show that there is a significant relationship between hospitalization (hospitalization) and parental anxiety, parental anxiety can hinder the process of LBW treatment (Dyna Apryani, 2013).The Separation between parents and newborn babies, the inability of parents to look after and care for babies, the inability to protect babies from pain, the use of technology and tools in intensive rooms, and the critical condition of babies cause parents to be stressed (Mundy, 2010).

LBW can be treated at home if the baby's health condition is stable. Early discharge is what mothers expect when they feel ready and able to care for their babies at home. Mothers who have confidence in their abilities will have a positive impact on the interaction between mother and baby. The results showed that the mother's knowledge about the implementation of low birth weight care at home was still in the low category. Mother has less knowledge in maintaining temperature and warmth of $75.56 \%$ (Ningsih, Suryantoro \& Nurhidayati, 2017).

Mothers need opportunities to get to know their babies and learn to feel ready to meet their babies' needs. One of the health service efforts for LBW is health education provided by nurses to mothers regarding baby care, mother's self-care, home safety, security and immunization (Maryunani, 2013). Research Randomized clinical trial in preterm infants with gestational age less than 32 weeks or birth weight less than 1500 grams carried out early intervention such as teaching parents how to perform FMD and exclusive breastfeeding from the time the baby is hospitalized to returning home. Research shows that early, ongoing intervention at home by families can have a positive impact on the development of their babies (Silveira et al., 2018).

Based on the results of research on the experiences of mothers in caring for babies with preterm and low birth weight, it shows that mothers who have low birth weight have lower levels of confidence in carrying out baby care compared to mothers who give birth to normal birth weight babies (Padila, Amin
\& Rizki, 2018). The results of the research on the effect of education in planning to go home on the level of anxiety and the level of self-efficacy of mothers in caring for LBW showed that education was able to reduce anxiety and increase the self-efficacy of mothers in caring for LBW (Suyami, 2013).

Research on the experiences of mothers in caring for babies with preterm and low birth weight shows that mothers who have LBW have lower levels of confidence in carrying out baby care compared to mothers who give birth to normal birth weight babies(Padila, Amin \& Rizki, 2018). The results of a preliminary study conducted at the Kendal Regional Hospital using a questionnaire measuring device with 8 LBW parents in Perinatology rooms throughout Kendal Regency, 5 parents were not ready to care for LBW. Education for parents who have LBW is one of the nurses' efforts to meet the needs of parents in caring for their babies. Materials that need to be conveyed to parents who have LBW include the fulfillment of infant nutrition, monitoring of respiratory responses, prevention of changes in body temperature, prevention of infection, and fostering stimulation (touch and massage) as well as improving parent-infant relationships. Based on the existing phenomena, the researchers are interested in researching on the readiness of parents in caring for low birth weight (LBW) babies through LBW care education

\section{METHODS}

This research is a quantitative study, using a quasi-experimental design with pre-post-testwith control. The population of this study was parents who had LBW babies in Kendal District Hospital with the sampling technique using accidental sampling, the total sample was 40 parents with LBW babies. The sample was classified into two groups, namely, 20 respondents as the intervention group and 20 respondents as the control group. The inclusion criteria in this study were parents who had babies with birth weight less than 2500 grams and were treated in Kendal Hospital and were able to read, while the exclusion criteria in this study were infants died, infants were referred to other hospitals and parents could not be communicated or seriously ill.Parents with LBW babies in the treatment group will get education about LBW care from the researcher, while parents with LBW in the control group do not get education about LBW care from the researcher however, parents in the control group still get service from the nurse who is in charge of the perinatology room about baby care LBW according to hospital policy. 
The statistical test in this study used the Mc Nemar and Chi-Square test. Data analysis to determine the differences in parental readiness before and after being given child nursing intervention through education using the Mc Nemar test, while to determine the effect of child nursing intervention through LBW care education on parental readiness in caring for LBW using the Chi-Square.The questionnaire of parental readiness in caring for LBW consists of 35 statements using a Likert scale, includes the readiness of the mother to meet nutritional needs, thermoregulation, patency of the airway and prevention of infection in LBW.

The validity and reliability of the questionnaire were tested at RSUD Dr. H. Soewondo Kendal from 17 May to 4 June 2017 using 20 respondents and analyzed using a computer program. Based on the validity test, the results of $r$ count from 35 statements regarding readiness are 0.671-915 > table 0.444 meaning that 35 question items are declared valid, while for the reliable test it is known that the $p$ value is 0.980 , the p value of the statement items is close to 1 or $>r$ table 0.444 then the research question item is declared reliable. Researchers collected pre-test data to measure the level of parental readiness in caring for LBW by giving questionnaires to respondents to be filled in before the control and intervention groups. Researchers conducted a pretest by giving a questionnaire to mothers with LBW, researchers provided interventions in the form of education about LBW care including maintenance of respiration, body temperature, fulfilling nutritional needs and how to prevent infection in LBW to respondents while the baby was hospitalized. A post test questionnaire will be given to parents if the baby is allowed to go home from the hospital by the responsible doctor. This research has obtained ethics appropriate information number 34 / KEPK / RSI / VII / 2020 from the Health Research Ethics Committee Kendal Islamic Hospital.

\section{RESULTS}

Based on table 1, it shows that the majority of mothers have a Senior high school education level, namely $37.5 \%$, aged $>=25$ years as much as $72.5 \%$, most parents are ready to care for LBW, namely $67.5 \%$, while mothers who are not ready to care for LBW, namely $32.5 \%$, the majority of mothers do not work as much as $57.5 \%$.

Based on table 2, it can be explained that the mean score of parental readiness in caring for low birth weight babies given education is 117.45 with a standard deviation of 6.653 , while the readiness of parents who are not given LBW care education has an average score of 105.85 with a standard deviation of 5.363. The statistical test results obtained $P$ value 0.000 , it can be concluded that there is a difference in the readiness of parents in caring for LBW between those who provide education and not given education about LBW care.

Table 3 explains that respondents who did not receive the educational intervention for LBW care, most of respondents were not ready to care for LBW, namely 11 respondents or $91.7 \%$, while the majority of respondents who were given intervention in the form of LBW care education were ready to care for LBW, namely 19 respondents or $67.9 \%$. The results of the analysis using Chi-Square obtained a P-value of 0.002 , it can be concluded that there is an effect of the effect of providing LBW care education on parental readiness to care for LBW.

\section{DISCUSSION}

The results of this study indicate that there are differences in parental readiness in caring for LBW before and after being given LBW care education and there is an effect of providing LBW care education on parental readiness to care for LBW, in line with the research results which mothers' knowledge of good LBW care can increase the baby's weight (Ningsih, Suryantoro \& Nurhidayati, 2017). Mothers with LBW are at risk of experiencing psychological stress and postpartum depression. The results showed that the majority of mothers experienced mild anxiety (Tane, Masitoh \& Rustina, 2020)

LBW is an unexpected birth by the parents. LBW has a smaller body appearance and immature organ functions have a negative impact on maternal psychology, namely anxiety and lead to parental unpreparedness in treating LBW. Knowledge about caring for low birth weight is the basis of the readiness of mothers in caring for LBW, nurses have an important role as educators in giving influence in the process of shaping the readiness of mothers in caring for LBW. The provision of LBW care education is a process in preparing parents to be able to carry out independent care to meet their baby's needs. The results of data analysis using the Mann Whitney and Wilcoxon test in Rahayu's study showed that there were differences in maternal independence between the group of mothers who were given assistance and the Kangaroo Method Care module and the control group with $p$ value $<0.001$. In the group of mothers who were given assistance and modules on kangaroo care methods, mothers were more independent 
Tabel 1. Respondent Characteristics

\begin{tabular}{lcc}
\hline Characteristics & f & \% \\
\hline Level of education & & 25 \\
primary school & 10 & 32.5 \\
junior high school & 13 & 37.5 \\
senior High School & 15 & 5 \\
College & 2 & \\
\hline Age & & 27.5 \\
less than 25 years & 11 & 72.5 \\
more than or 25 years & 29 & \\
\hline The Readiness of parents to care for LBW & & 67.5 \\
Ready & 27 & 32.5 \\
$\quad$ Not ready & 13 & 57.5 \\
\hline Profession & & 42.5 \\
Doesn't work & 23 & \\
Work & 17 & \\
\hline
\end{tabular}

Tabel 2. Distribution Mean Readiness of Parents in Caring for LBW

\begin{tabular}{lcccc}
\hline & Mean & SD & SE & P value \\
\hline Not given LBW care education & 105.85 & 5.363 & 1.199 & \multirow{2}{*}{0.000} \\
Provide LBW care education & 117.45 & 6.653 & 1.448 & \\
\hline
\end{tabular}

Tabel 3. The Influence of Providing Maternity Care Education

\begin{tabular}{|c|c|c|c|c|c|c|c|c|}
\hline & & \multicolumn{4}{|c|}{$\begin{array}{l}\text { The Readiness of parents to care for } \\
\text { LBW }\end{array}$} & \multirow{2}{*}{\multicolumn{2}{|c|}{ TOTAL }} & \multirow{2}{*}{$\begin{array}{c}\rho- \\
\text { value }\end{array}$} \\
\hline & & \multicolumn{2}{|c|}{ Not Ready } & \multicolumn{2}{|c|}{ Ready } & & & \\
\hline & & $\mathbf{n}$ & $\%$ & $\mathbf{n}$ & $\%$ & $\mathbf{n}$ & $\%$ & \multirow{5}{*}{0.002} \\
\hline \multirow{4}{*}{ Intervention } & Not given & 11 & 91.7 & 9 & 32.1 & 20 & 50 & \\
\hline & $\begin{array}{l}\text { LBW care } \\
\text { education }\end{array}$ & & & & & & & \\
\hline & Provide & 1 & 8.3 & 19 & 67.9 & 20 & 50 & \\
\hline & $\begin{array}{l}\text { LBW care } \\
\text { education }\end{array}$ & & & & & & & \\
\hline
\end{tabular}

than the control group(Rahayu, 2016).

The implementation of educational programs during discharge planning which is carried out for three days can increase the knowledge and skills of mothers caring for premature babies, this is evidenced by the results of research which show that there is a significant difference between the average score of knowledge of mothers caring for premature babies, scores of breastfeeding skills, and kangaroo method care skills scores (PMK) before and after being given education during discharge planning with a p value of 0.001 (Julianti, Rustina \& Defi, 2019). Another study showed that $86.4 \%$ of respondents experienced a decrease in anxiety and $18.2 \%$ of respondents expe- rienced an increase in self-efficacy after being given an education. The results showed that there were significant differences in the level of anxiety and selfefficacy in the intervention group, while in the control group there was no significant difference (Suyami, Rustina \& Agustini, 2014).

Providing education and involving parents in caring for low birth weight while the baby is hospitalized will have a positive impact. Research results by Rustina Y et al (2014) obtained p value $<0.05$, this indicates that the family empowerment program is effective in increasing maternal knowledge and increasing immunization status in the group Interventions with implications for premature LBW are con- 
tinually exposed to various health problems so that they can be prevented by empowering parents (Rustina et al., 2014). LBW can be an indicator of public health from maternal health, nutrition, provision of health services, and poverty, LBW conditions that experience immaturity of organ systems and respiratory disorders can be the main cause of child mortality (Cutland et al., 2017). LBW mortality can be caused by asphyxia, respiratory distress syndrome, infection and hypothermia. LBW can be cared for at home if the baby's condition is stable, such as the baby can suck well, does not experience respiratory problems and there are no danger signs to the baby. Parents physically and psychologically must be able and ready to treat LBW at home after returning from the hospital (Proverawati \& Ismawati, 2010).The role of nurses as educators is very important in preparing parents to care for LBW at home, because by providing education it is hoped that there will be an increase in the knowledge and ability of parents in caring for LBW, in accordance with one of the results of research which shows that the better the role of nurses as educators, the more positive patient perceptions of disease, this can impact the less threat of disease felt by patients (Anggraeni, Widayati, \& Sutawardana, 2020).

The results of the study of 33 mothers who had LBW showed that the majority of the mother's knowledge level about the management of LBW was in the moderate category, namely $63.6 \%$, and the majority of mothers' behavior in LBW care was also in the sufficient category, namely $72.7 \%$ with the conclusion. Maternal behavior in LBW care with a significant p-value 0.025 (Yuliani, 2017).

Interventions given to mothers who have a LBW in the form of education about LBW care, are able to increase the readiness of mothers to care for LBW. It is hoped that the readiness of the mother in caring for LBW can prevent the baby from being hospitalized again after being discharged from the hospital so that the baby can grow and develop optimally.

\section{CONCLUSION}

Based on the statistical test, this study shows that there are differences in parent readiness to care for LBW before and after being given education about LBW care. Based on this analysis, it can be concluded that there is an effect of giving child nursing interventions through LBW care education on parents' readiness to care for LBW. Providing education to parents with LBW is one of the implementa- tions of child nursing that nurses can do to prepare parents to care for LBW.

\section{ACKNOWLEDGMENTS}

All of respondent and staff in Region Kendal Hospital and ethical committee of Kendal Islamic Hospital. Researchers would like to thank RISTEKBRIN who has financedthis research in a research scheme Beginner Lecturers for the 2020 fiscal year and thanks to the Chairman of STIKES Kendal who have support in this research.

\section{REFERENCES}

Anggraeni, N. C., Widayati, N. and Sutawardana, J. H. 2020. Peran Perawat sebagai Edukator terhadap Persepsi Sakit pada Pasien Diabetes Mellitus Tipe 2 Kabupaten Jember. Jurnal Pendidikan Keperawatan Indonesia. doi: 10.17509/jpki.v6i1.24364.

Central Java Province Health Office 2017. Profil Kesehatan Provinsi Jawa Tengah 2017. Dinkes Jateng.

Cutland, C. L. et al. 2017. Low birth Weight: Case Definition \& Guidelines For Data Collection, Analysis, And Presentation Of Maternal Immunization Safety Data. Vaccine. doi: 10.1016/j.vaccine.2017.01.049.

Dyna Apryani 2013. Hubungan Yang Signifikanantara Lama Rawat (Hospitalisasi) Dengankecemasan Orang Tua Di Ruang Anak RSUD Cianjur. JKS, 8(2). Available at: http://dx.doi.org/10.20884/ 1.jks.2013.8.2.47.

Julianti, E., Rustina, Y. and Defi, E. 2019.n Program Perencanaan Pulang Dapat Meningkatkan Pengetahuan Dan Keterampilan Ibu Yang Melahirkan Bayi Prematur Merawat Bayinya. Jurnal Keperawatan Indonesia. doi: 10.7454/jki.v22i1.540.

Maryunani, A. 2013. Asuhan Bayi dengan Berat Badan Lahir Rendah. Jakarta: CV Trans Info Media.

Mundy, C. A. 2010. Assessment of Family Needs in Neonatal Intensive Care Units. American Journal of Critical Care, 19(2), pp. 156-163. doi: 10.4037/ajcc2010130.

Ningsih, S. R., Suryantoro, P. and Nurhidayati, E. 2017. Hubungan Pengetahuan Ibu Tentang Perawatan Bayi Berat Lahir Rendah (BBLR) Dengan Kenaikan Berat Badan Bayi. Jurnal Kebidanan dan Keperawatan 
Aisyiyah, 12(2), pp. 149-157. doi: 10.31101/ jkk.306.

Padila, P., Amin, M. and Rizki, R. 2018. Pengalaman Ibu dalam Merawat Bayi Preterm yang Pernah dirawat di Ruang Neonatus Intensive Care Unit Kota Bengkulu. Jurnal Keperawatan Silampari, 1(2), pp. 1-16. doi: 10.31539/jks.v1i2.82.

Proverawati, A \& Ismawati, C. 2010. Berat Badan Lahir Rendah. Yogyakarta: Nuha Medika.

Putra, P. J. 2016. Insiden dan Faktor-Faktor yang Berhubungan dengan Sepsis Neonatus di RSUP Sanglah Denpasar. Sari Pediatri. doi: 10.14238/sp14.3.2012.205-10.

Rahayu, S. 2016. Pengaruh Pendampingan Dan Pemberian Modul Kangaro Mother Care Terhadap Kemandirian Ibu Nifas Merawat Bblr Di Rumah. Jurnal Ilmiah Bidan, 1(3), pp. 55-61.

Reeder, S. J., \& Griffin, K. 2011. Keperawatan Maternitas: Kesehatan Wanita, Bayi \& Keluarga. Jakarta: EGC.

Rukiyah. 2012. Asuhan Neonatus, Bayi dan Anak Balita. Jakarta: CV Trans Info Media.

Rustina, Y. et al. 2014. The Influence of Family Empowerment on the Health Status of Low Birth Weight Infant in Jakarta. Makara Journal of Health Research, 18(1), pp. 19-24. doi: 10.7454/msk.v18i1.3089.

Sembiring, J. B. 2019. Buku Ajar Neonatus, Bayi, Balita, Anak Pra Sekolah. Yogyakarta: CV Budi Utama.

Silveira, R. C. (2018). Early Intervention Program For Very Low Birth Weight Preterm Infants And Their Parents?: A Study Protocol. BMC Pediatrics, pp. 1-11.

Suyami 2013. Pengaruh Edukasi dalam Perencanaan Pulang terhadap Tingkat Kecemasan dan Tingkat Efikasi Diri Ibu dalam Merawat BBLR. Available at: lib.ui.ac.id/file?file=pdf/ abstrak-20335906.pdf\%0A\%0A.

Suyami, Rustina, Y. and Agustini, N. 2014. Pengaruh Edukasi Terhadap Tingkat Kecemasan dan Tingkat Efikasi Diri Ibu Dalam Merawat BBLR. Prosiding Seminar Nasiona.

Tane, R., Masitoh, S. and Rustina, Y. 2020. Factors Influencing Anxiety In Mothers Of Low Birth Weight Infants. Pediatric Reports. doi: 10.4081/pr.2020.8701.

Wahyu Hendiyanto, A. 2014. Tingkat Kecemasan Ibu Yang Mempunyai Bayi Bblr Di Ruang Prinatologi RSUD Harjono. Available at: http://www.onesearch.id/Record/
IOS2857.599/Details.

Yuliani, H. 2017. Hubungan Pengetahuan Ibu Tentang Penatalaksanaan Bayi Berat Lahir Rendah (BBLR) Dengan Perilaku Ibu Dalam Perawatan BBLR Di RSUD Wates. Sekolah Tinggi Ilmu Kesehatan Jenderal Achmad Yani. 